\title{
Full genome sequence of guinea fowl coronavirus associated with fulminating disease
}

\author{
Mariette F. Ducatez $\cdot$ Etienne Liais • \\ Guillaume Croville $\cdot$ Jean-Luc Guérin
}

Received: 9 December 2014/ Accepted: 13 February 2015/Published online: 25 February 2015

(c) Springer Science+Business Media New York 2015

\begin{abstract}
Guinea fowl coronavirus (GfCoV), a recently characterized avian coronavirus, was identified from outbreaks of fulminating disease (peracute enteritis) in guinea fowl in France. The full-length genomic sequence was determined to better understand its genetic relationship with avian coronaviruses. The full-length coding genome sequence was 26,985 nucleotides long with 11 open reading frames and no hemagglutinin-esterase gene: a genome organization identical to that of turkey coronavirus $\left[5^{\prime}\right.$ untranslated region (UTR)-replicase (ORFs 1a, 1ab)spike (S) protein-ORF3 (ORFs 3a, 3b)—small envelop (E or 3c) protein-membrane (M) protein-ORF5 (ORFs $4 \mathrm{~b}$, $4 \mathrm{c}, 5 \mathrm{a}, 5 \mathrm{~b})$-nucleocapsid $(\mathrm{N})$ protein (ORFs $\mathrm{N}$ and $6 \mathrm{~b}$ ) $3^{\prime}$ UTR]. This is the first complete genome sequence of a $\mathrm{GfCoV}$ and confirms that the new virus belongs to group gammacoronaviruses.
\end{abstract}

Keywords Coronavirus - Nidovirus - Guinea fowl · Genome organization · Fulminating disease

\section{Introduction}

Coronaviruses (CoVs) are enveloped viruses with positivesense, non-segmented RNA genomes of 25-32 kb. CoVs

Edited By William Dundon

Electronic supplementary material The online version of this article (doi:10.1007/s11262-015-1183-z) contains supplementary material, which is available to authorized users.

M. F. Ducatez $(\bowtie) \cdot$ E. Liais · G. Croville · J.-L. Guérin INRA, UMR 1225 and Université de Toulouse, INP, ENVT, 23 Chemin des Capelles, 31076 Toulouse, France

e-mail: m.ducatez@envt.fr infect a wide range of hosts causing various degrees of morbidity and mortality. Group I CoVs (alphacoronaviruses) contain viruses that infect not only humans $(\mathrm{HCoV}-229 \mathrm{E}$ and HCoV-NL63) but also cats and dogs (with feline CoV and canine $\mathrm{CoV}$, respectively), or pigs (with the porcine transmissible gastroenteritis virus, TGEV for example). Similarly, group II CoVs (betacoronaviruses) may infect humans (examples: HCoV-OC43, HCoV-HKU1, severe acute respiratory syndrome (SARS)-related $\mathrm{CoVs}$ or the recently emerged MERS-CoV), horses (with $\mathrm{ECoV}$ ), or cattle (with $\mathrm{BCoV}$ ). In contrast, group III CoVs (gammacoronaviruses) primarily infect birds: chickens, peafowl, and partridges harbour infectious bronchitis virus (IBV) while turkeys have turkey $\mathrm{CoV}(\mathrm{TCoV})$ and guinea fowl may be infected with guinea fowl $\mathrm{CoV}$ (GfCoV). Gammacoronavirus strains have however been isolated from a whale and a wild felid [1]. Group IV CoVs (deltacoronaviruses) have been detected in birds (with $\mathrm{BuCoV}$, $\mathrm{MuCoV}, \mathrm{SpCoV}$, etc.), or pigs (with porcine deltacoronavirus) [2]. Interestingly CoVs of the groups I, II, and IV have been detected in Chiroptera (bats), thought to be the reservoir of CoVs [3, 4].

In the present study, we focused on a new member of the group III CoVs, GfCoV, and aimed at sequencing its full genome to better understand its molecular relationship with gammacoronaviruses.

\section{Materials and methods}

To determine the full genome of gammaCoV/guinea fowl/ France/s/2011 (GfCoV/FR/2011), we first analysed the data generated on a MiSeq Illumina platform as previously described [5]. Briefly, pooled intestinal contents of experimentally infected guinea poults were clarified, 
Table 1 Genes and coding regions for GfCoV/FR/2011

\begin{tabular}{|c|c|c|c|c|c|c|c|c|c|c|}
\hline ORF & $\begin{array}{l}\text { Location } \\
\text { (GfCoV) }\end{array}$ & $\begin{array}{l}\text { Size } \\
\text { in nt } \\
(\mathrm{GfCoV})\end{array}$ & $\begin{array}{l}\text { Size } \\
\text { in aa } \\
(\mathrm{GfCoV})\end{array}$ & $\begin{array}{l}\text { Size in aa } \\
(\mathrm{TCoV} / \mathrm{VA}- \\
74 / 03)^{1}\end{array}$ & $\begin{array}{l}\text { Size in aa } \\
\text { (TCoV/TX- } \\
\text { GL/01) }{ }^{1}\end{array}$ & $\begin{array}{l}\text { Size in aa } \\
\text { (TCoV/TX- } \\
1038 / 98)^{1}\end{array}$ & $\begin{array}{l}\text { Size in aa } \\
(\mathrm{TCoV} / \mathrm{IN}- \\
517 / 94)^{1}\end{array}$ & 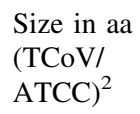 & $\begin{array}{l}\text { Size in aa } \\
(\mathrm{TCoV} / \\
540)^{2}\end{array}$ & $\begin{array}{l}\text { Size in aa } \\
(\mathrm{TCoV} / \\
\left.\mathrm{MG}^{3}\right)^{3}\end{array}$ \\
\hline $5^{\prime} \mathrm{UTR}^{*}$ & $1-463$ & $>463$ & - & - & - & - & - & - & - & - \\
\hline $1 \mathrm{a}$ & $464-12,307$ & 11,844 & 3948 & 3947 & 3949 & 3950 & 3952 & 3957 & 3945 & 3951 \\
\hline $1 \mathrm{ab}(/ 1 b)$ & $\begin{array}{l}464-12,280 \\
\text { and } 12,280- \\
20,346\end{array}$ & $\begin{array}{l}19884 \\
8067\end{array}$ & $\begin{array}{l}6628 \\
2689\end{array}$ & 6596 & 6602 & 6602 & 6605 & 2654 & 2652 & 6601 \\
\hline S & $20,294-23,914$ & 3621 & 1207 & 1226 & 1225 & 1224 & 1226 & 1203 & 1203 & 1226 \\
\hline $3 a$ & $23,917-24,087$ & 171 & 57 & 57 & 57 & 57 & 57 & 57 & 57 & 57 \\
\hline $3 b$ & $24,090-24,281$ & 192 & 64 & 64 & 64 & 64 & 64 & 64 & 64 & 64 \\
\hline$E(3 c)$ & $24,265-24,540$ & 276 & 92 & 99 & 109 & 99 & 99 & 103 & 99 & 99 \\
\hline M & $24,543-25,214$ & 672 & 224 & 223 & 225 & 223 & 223 & 223 & 222 & 223 \\
\hline $4 b$ & $25,218-25,499$ & 282 & 94 & 94 & 94 & 94 & 94 & 94 & 94 & 94 \\
\hline $4 c$ & $25,423-25,533$ & 111 & 37 & & & & & 52 & 56 & \\
\hline $5 \mathrm{a}$ & $25,578-25,772$ & 195 & 65 & 65 & 65 & 65 & 65 & 65 & 65 & 65 \\
\hline $5 b$ & $25,772-26,011$ & 240 & 80 & 82 & 82 & 92 & 82 & 82 & 80 & 82 \\
\hline $\mathrm{N}$ & $25,957-27,183$ & 1227 & 409 & 409 & 409 & 409 & 409 & 409 & 409 & 409 \\
\hline $6 b$ & $27,191-27,445$ & 255 & 85 & & & & & 74 & 73 & \\
\hline $3^{\prime} \mathrm{UTR}^{*}$ & 27,447 & 27,471 & - & - & & & & - & - & - \\
\hline
\end{tabular}

* Incomplete sequences, nt: nucleotides, aa: amino acids

1 as described in [10]

2 as described in [3] with $1 \mathrm{~b}$ described rather than $1 \mathrm{ab}$ (size in aa in italic font)

3 as described in [8]

ultracentrifuged, and treated with nucleases to concentrate encapsidated viral material. RNA was extracted, and a random RT-PCR was performed to generate unbiased PCR products of about $300 \mathrm{bp}[5,6]$. The sequences generated that matched with avian CoVs sequences, as determined using GAAS software [7], were extracted for further analysis and visualized using integrative genomics viewer (IGV) with the closest blast hit as reference genome: TCoV MG10 (accession number: EU095850) [8]. Primers were designed based on the known sequence data to amplify missing genome fragments by PCR. Sanger sequencing was then performed with PCR primers. The full genome sequence was submitted to EMBL and was attributed the following accession number: [LN610099]. Sequence analysis was carried out using BioEdit version 7.0.8.0 [9], muscle for the alignment [10], and mega version 5.05 for the phylogeny [11].

\section{Results and discussion}

The gfCoV-generated sequences were assembled into one contiguous coding sequence of 26,985 nucleotides. The entire genome had a GC content of $38.3 \%$, identical to the turkey coronavirus (TCoV) MG10 genome [12]. GfCoV and TCoV genomes have the same organization: (i) a $5^{\prime}$ untranslated region (UTR), (ii) two large slightly overlapping ORFs coding for the replicase: $1 \mathrm{a}$ and $1 \mathrm{ab}$, (iii) gene coding for the spike (S) protein, (iv) ORF3 (ORFs 3a, 3b), (v) gene coding for the small envelop (E or 3c) protein, (vi) gene coding for the membrane (M) protein, (vii) ORF5 (4b and $4 c, 5 a, 5 b)$, (viii) genes coding for the nucleocapsid (N) protein (ORFs N and 6b), and (ix) $3^{\prime}$ UTR (Table 1). The multiprotein on single ORFs is generated by alternative translation. While the role of avian coronavirus (IBV) structural proteins is known: binding to RNA, nucleocapsid formation and role in cell-mediated immunity for $\mathrm{N}$; virus budding site determination, role in virus particle assembly and in interferon-induction, interaction with viral nucleocapsid for $\mathbf{M}$; association with viral envelop, role in virus particle assembly and putatively in apoptosis for $\mathrm{E}$; binding to cellular receptors, induction of fusion between viral and cellular membranes, induction of neutralizing antibodies and role in cell-mediated immunity for $\mathrm{S}$; little is known on the function of non-structural proteins. It has mainly been shown that they are not essential for virus replication in vitro but likely help the virus replicate in vivo $[13,14]$. The proteins $3 \mathrm{a}, 3 \mathrm{~b}, 4 \mathrm{~b}, 5 \mathrm{a}$, and $\mathrm{N}$ were of the same size. Sizes of other proteins varied, but within the range observed previously between different TCOV strains. 
A
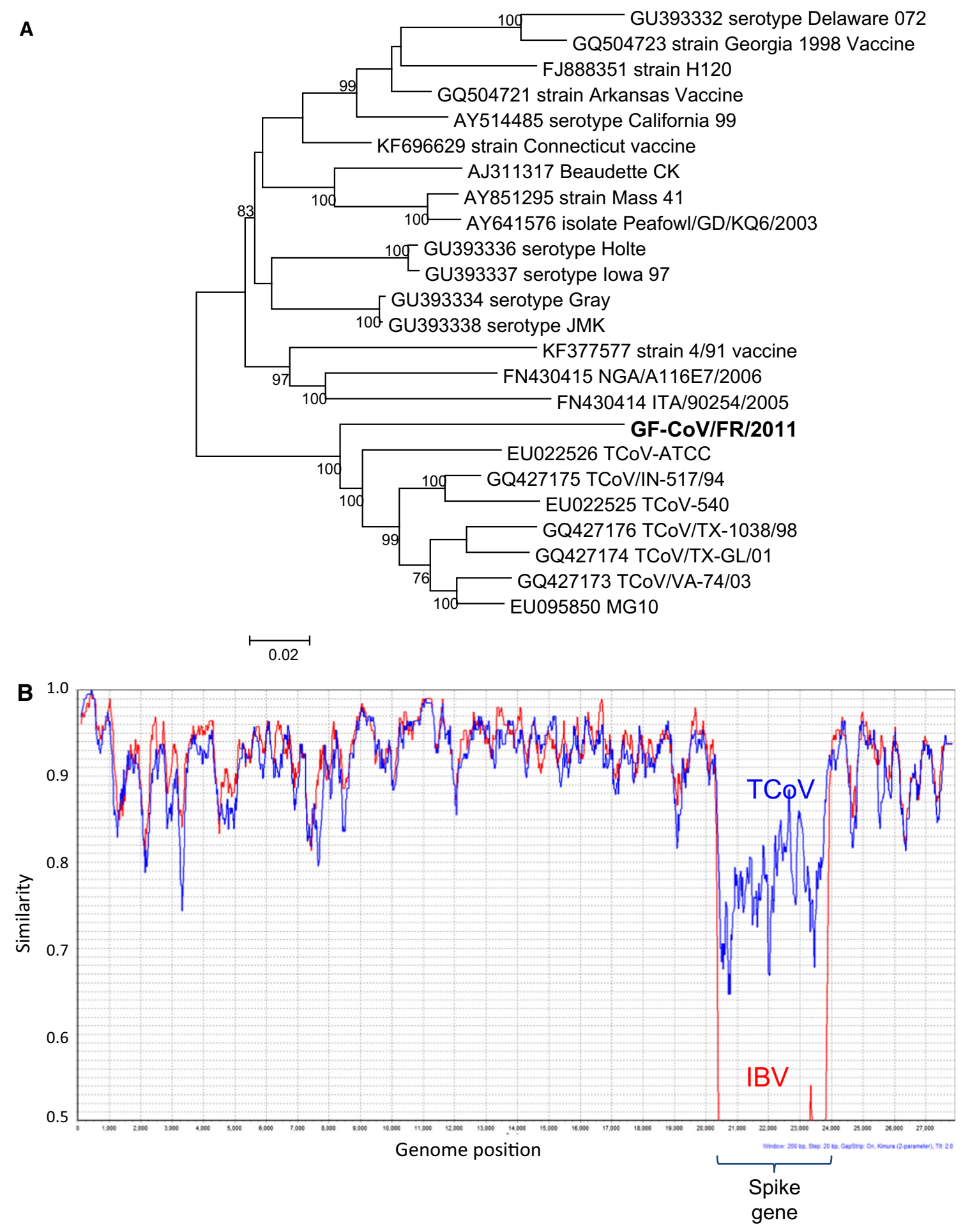

Fig. 1 Molecular comparison of the full genome of GfCoV/FR/2011 and avian gammacoronaviruses. a Phylogenetic analysis of the complete genomes of GfCoV/FR/2011 (in bold font) in relation to all available full genomes of turkey coronaviruses (TCoV) and full genomes of representative infectious bronchitis viruses (IBV) at the nucleotide level. The tree was generated using MEGA 5.05 and the maximum likelihood method. Bootstrap values (500 replicates) $>75$ are indicated on the nodes. b Simplot analysis of full genomic sequence for GfCoV/FR/2011 (query) and its closest TCoV (in blue) and IBV (in red) blast hits. The spike gene area is indicated on the plot (Color figure online) 
Interestingly, GfCoV/FR/2011 harboured a shorter small envelop protein than its TCoV counterparts (Table 1). Further studies are warranted to understand the impact of avian CoVs protein sizes in the biology of the viruses.

Phylogenetic analysis on the full genome of GfCoV/FR/ 2011 showed it clearly clustered with North American TCoV strains (Fig. 1a, supported by a high bootstrap value of 100), as it was observed previously for the $S$ gene [5]. The genetic distance between GfCoV/FR/2011 and TCoV ranged between 10.7 and $11.4 \%$, while genetic distances between GfCoV/FR/2011 and representative IBV strains were larger and varied between 13.5 and $15.0 \%$ (Supplementary Table). A simplot analysis comparing the GfCoV/ FR/2011 full genome to its closest TCoV and IBV Blast hits showed that the three genomes are highly similar throughout the genome $(74-100 \%$ similarity, with no significantly higher identity of GfCoV/FR/2011 with TCoV or IBV genomes), except for the S gene (Fig. 1b). GfCoV S gene was indeed more closely related to TCoV $S$ than to IBV $\mathrm{S}$ genes but also more distinct to both viruses on the $\mathrm{S}$ gene than on the rest of its genome $(<50 \%$ identity for IBV and 65-90 \% identity with TCoV S genes, Fig. 1b), suggesting a recombination event as was hypothesized for the origin of $\mathrm{TCoV}$ [15]. A parallel evolution from a common ancestor with a much higher substitution rate on the $S$ gene than on the rest of the genome can however not be ruled out at this stage.

The present study showed that GfCoV/FR/2011 harbours a genome organization very similar to that of $\mathrm{TCoV}$ strains. In addition, and again like TCoV, GfCoV/FR/2011 likely originated from a recombination event between an IBV-like (or TCoV-like) virus that would have given most of its genome and a so far unknown $\mathrm{CoV}$ that would have contributed by its spike gene. Despite the similarity of their genomes and their enteric tropism, TCoVs often cause mild clinical signs while GfCoVs are usually associated with extremely high mortalities in their host, suggesting strikingly different host-virus interactions. Further studies are ongoing to understand the host range of GfCoV/FR/2011 and its determinants of pathogenicity.

Acknowledgments This work was supported by the 'EPICOREM' grant of the Agence Nationale de la Recherche (ANR), by the French
Comité Interprofessionnel de la Pintade (CIP) and by the French Ministry of Agriculture. Etienne Liais is supported by a scholarship from French Ministry of Agriculture and Region Midi-Pyrénées. We would like to thank the Plateforme bioinformatique Toulouse MidiPyrénées, UBIA, INRA, 31326, Castanet-Tolosan, France; the GeTPlaGe, INRA ENVT UMR444, Laboratoire de Génétique Cellulaire 31326, Castanet-Tolosan, France; and the Plateau de Génomique GeT-Purpan, UDEAR UMR 5165 CNRS/UPS, CHU PURPAN, Toulouse, France, for technical assistance with sequencing and sequence analysis.

\section{References}

1. D. Gavier-widen, N. Decaro, C. Buonavoglia. in Infectious Diseases of Wild Mammals and Birds in Europe, ed. by D.J. GavierWiden, A. Meredith (Blackwell, 2012), pp. 234-240

2. J.F. Chan, K.S. Li, K.K. To, V.C. Cheng, H. Chen, K.Y. Yuen, J. Infect. 65, 477-489 (2012)

3. A. Balboni, M. Battilani, S. Prosperi, New Microbiol. 35, 1-16 (2012)

4. H. Chen, Y. Guan, X. Fan, Hong Kong Med. J. 17(Suppl 6), 36-40 (2011)

5. E. Liais, G. Croville, J. Mariette, M. Delverdier, M.N. Lucas, C. Klopp, J. Lluch, C. Donnadieu, J.S. Guy, L. Corrand, M.F. Ducatez, J.L. Guerin, Emerg. Infect. Dis. 20, 105-108 (2014)

6. J.G. Victoria, A. Kapoor, L. Li, O. Blinkova, B. Slikas, C. Wang, A. Naeem, S. Zaidi, E. Delwart, J. Virol. 83, 4642-4651 (2009)

7. F.E. Angly, D. Willner, A. Prieto-Davo, R.A. Edwards, R. Schmieder, R. Vega-Thurber, D.A. Antonopoulos, K. Barott, M.T. Cottrell, C. Desnues, E.A. Dinsdale, M. Furlan, M. Haynes, M.R. Henn, Y. Hu, D.L. Kirchman, T. McDole, J.D. McPherson, F. Meyer, R.M. Miller, E. Mundt, R.K. Naviaux, B. RodriguezMueller, R. Stevens, L. Wegley, L. Zhang, B. Zhu, F. Rohwer, PLoS Comput. Biol. 5, e1000593 (2009)

8. H. Thorvaldsdottir, J.T. Robinson, J.P. Mesirov, Brief. Bioinform. 14, 178-192 (2013)

9. T. Hall, Nucleic Acids Symp. 41, 95-98 (1999)

10. R.C. Edgar, Nucleic Acids Res. 32, 1792-1797 (2004)

11. K. Tamura, D. Peterson, N. Peterson, G. Stecher, M. Nei, S. Kumar, Mol. Biol. Evol. 28, 2731-2739 (2011)

12. M.H. Gomaa, J.R. Barta, D. Ojkic, D. Yoo, Virus Res. 135, 237-246 (2008)

13. D. Cavanagh, J. Gelb Jr., in Diseases of Poultry, vol. 12, ed. by Y.M. Saif (2008)

14. M.M.C. Lai, S. Perlman, L.J. Anderson, in Fields Virology, 5th edn., vol. 1, ed. by D.M. Knipe, P.M. Howley (2007)

15. M.W. Jackwood, T.O. Boynton, D.A. Hilt, E.T. McKinley, J.C. Kissinger, A.H. Paterson, J. Robertson, C. Lemke, A.W. McCall, S.M. Williams, J.W. Jackwood, L.A. Byrd, Virology 398, 98-108 (2010) 